\title{
The mediating effect of competitive strategy on the relationship between market development, product development and performance of manufacturing based SMEs in Nigeria
}

\author{
Sidi Bello Alkasim \\ Department of Marketing \\ Umaru Ali Shinkafi Polytechnic, Sokoto, Nigeria \\ School of Business Management, \\ College of Business, Universiti Utara, Malaysia
}

\author{
Haim Hilman \\ Abdul Manaf bin Bohari \\ School of Business Management, \\ Universiti Utara, Malaysia
}

\section{Keywords}

Firm performance, market development, product development, competitive strategy.

\begin{abstract}
The aim of this study is to examine the mediating effect of competitive strategy on the relationship between growth level strategies, and firm performance. Data was compiled from the manufacturing based SMEs operating in the North-West region of Nigeria, using cross-sectional research design. This study adopted cluster sampling and randomly selected 453 respondents and questionnaires were proportionately distributed and collected through personally administered method. PLS-SEM was used to test the hypotheses. The results found positive impact to both market development and product development on the SME performance. It is expected that market development and product development will improve the competitive advantage and enhance performance of manufacturing based SMEs. The study found that competitive strategy empirically mediates the relationship between the strategic growth of manufacturing based SMEs and performance. Therefore, the findings of this study contribute to the literature and practice of SMEs owners-managers, policy makers, and researcher with better understanding on the role of competitive strategy in mediating the relationship between growth strategies and firm performance. The study also assessed the effect size, as well as the predictive relevance. Finally, limitations and suggested for further studies were represented.
\end{abstract}

Corresponding authors: Sidi Bello Alkasim, Hilman Haim

Email addresses for corresponding author: alkasimsidi32@gmail.com, hilman@uum.edu.my

First submission received: 6th May 2017

Revised submission received: 8th July 2017

Accepted: 20th August 2017

\section{Introduction}

The focus of today's business operations, for both developed and developing countries, is how to improve Small and medium enterprises (SMEs), towards growth and sustainability. Hence, Small and medium enterprises (SMEs) are gaining more concerned from institutions, for example; NonGovernmental Organization (NGO), research institutions, practitioners and so along. Moreover, SMEs has been realized as the engine of economic growth and development, not only to the developing economies, equally the developed countries to benefits enormously from the SMEs (Kongolo 2010). SMEs contributes greatly to job creation, youth innovation, increases production, technology growth, resource utilization, GDP and above all the poverty reduction (Abiodun 2014; Washington 2014).

The United Nations Industrial Development Organization (UNIDO) confirmed that in most countries, SMEs account for about $50 \%$ to $70 \%$ of the businesses operating and contributes about $50 \%$ of the turnover generated from the private sector (UNIDO, 2016). For instance, statistics have shown that Ghana received $85 \%$ to total employment and $70 \%$ of GDP, where $92 \%$ of the enterprises operating in 
Ghana are SMEs, South Africa's SMEs contributes $62 \%$ and $57 \%$ to employment and GDP respectively. However, in Nigerian SMEs account for $98 \%$ of the total businesses operating, contribute only $25 \%$ to the total employment and 47\% of the annual GDP (SMEDAN \& NBS 2013; NBS \& SMEDAN, 2012; Kongolo, 2010; Irura, Onyango, \& Kerre, 2011).

However, in that respect, many strategies were implemented by firms, such as growth strategies (Hussain, Khattak, Rizwan, \& Latif, 2013; Weber, Geneste, \& Connell, 2015). Previous studies recognized that growth strategy can increase firm's sales, market share and enhance competitive advantage, for instance; market development and product development strategy can improve firm's competitiveness (Propfe, Kreyenberg, Wind, \& Schmid, 2013; person 2007; Tavakolizadeh, 2014). Few studies have establish the empirical relationship bewtween growth strategies and firm's growth, sustainability, and market performance (Hussain et al., 2013; Gmelin \& Seuring, 2014; Lamore, Berkowitz, \& Farrington, 2013). Though growth strategies were not directly examined on the firm performance and these studies were conducted in the Europe and Asian nations on servicing organizations.

Previous studies empirically prove that competitive strategies significantly influence firm's competitiveness, competitive advantage and enhance performance (Uchegbulam, Akinyele, \& Ibidunni, 2015; Teeratansirikool, Siengthai, Badir, \& Charoenngam, 2013; Rosli 2012; Wu, Gao, \& Gu, 2015; Banker, Mashruwala, \& Tripathy, 2014). Furthermore, competitive strategy enables an organization to produce greater value for its stockholders, and add more values to its customers (Wilson, 2012; Tanwar, 2013). For SMEs to remain competitive and maintain competitive advantage in a competitive environment, appropriate strategies should be integrated, configured, and rebuild firm's competency in order to sustain competitive advantage and enhance performance (Teece, Pisano, \& Shuen, 1997; Dauda \& Ismaila, 2013; Teece \& Pisano 1994). Strategically matching firm's based strategies is still at early stage (Beatrice, Ojera, Ochieng, \& Aila, 2015; Teece, 2012).

Specifically, no study found in the existing literature that looks into the mediating effect of competitive strategy on the relationship between growth level strategies and firm performance. Though very few surveys were found to have established the mediating effect of competitive strategy (HernándezPerlines, Moreno-García, \& Yañez-Araque, 2016; Lechner \& Gudmundsson, 2014; Soni \& Kodali, 2011). Therefore, the main objective of this study is to examine the mediating effect of competitive strategy on the relationship between growth strategies and firm performance.

\subsection{Literature Review}

\subsection{Firm performance}

Firm performance is one of the fundamental beliefs in strategic management literature. Firms are measured based on their performance (Prajogo \& Sohal, 2006). Hence, performance is determined by appropriate strategic choice, which improves firm's competitiveness, competitive advantage and creates superior performance (Ferreira \& Otley, 2009). In fact, to achieve competitive advantage, firms must integrate, reconfigure and rebuild strategies that are valuable to provide them with a competitive advantage and create sustainable performance over competitors (Teece \& Pisano, 1994; Teece et al., 1997). Kaplan and Norton (1996) argued that firm performance should be appraised as a multidimensional concept, which enables firms to assess the current level of their financial and non-finance position, besides both are important aspects of firm performance, which relates to the firm effectiveness. The current study adapts the firm performance measuremesnts developed by Kaplan and Norton, (1996) which provides a combination of serious coverage of firm performance called Balanced Score-Card (BSC).

\subsubsection{Market development}

Market development strategy is defined as a decision of an organization with the intent to increase the volume sales, revenue and sustain market share (Hussain et al., 2013). Therefore, MD focuses to improving firms to obtain new users in the current and potential market who may likely have other essential needs that are not being offered by competitors in the market (Leitner, 2014).

Nonetheless, for a firm to achieve competitiveness, MD strategy enables market expansion through marketing activities, in order to gain customers and market requirements by exploring into new market segment (Hussain et al., 2013). MD will allow SMEs to compete and improve their existing markets and provide them with sources of competitive advantage (Leitner, 2014; Titman, Wei, \& Xie, 
2013). MD would enable SMEs to capture more segments and increase sales volume and market share, this would help owners-managers with the ability to coordinate their operations. Market development significantly influence competitiveness and improve growth, in turn enhance firm performance (Hussain et al. 2013). MD strategy would enable SMEs to increase competitive advantage and improve performance. Thus, based on above the study hypothesize the following:

H1: Market development is significantly related to the firm performance.

\subsubsection{Product development}

Product development is defined as an essential strategy that enables firms to innovate and modify existing products with intention to add greater value to customers (Henrique, \& Gilberto, 2013), which creates firms to sustain competitive advantage. Product development is one of the critical strategies that gives firm the ability to manage their product lifecycle effectively (Gmelin \& Seuring, 2014). Moreover, product development provides firms to operates in line with the trend of the market changes, which support firms to update and or create a new product that will improve firm competitive advantage and enhance performance (FME, 2003). SMEs can succeed in this capability, through effective research and development, marketing capabilities, and communication with customer to enable effective product development.

Hussain et al. (2013) examined the relationship between product development, environment and firm growth, and reported that PD is positive and significant related to firm growth. Firm's product innovation and product modification are processes of product development strategy, PD creates valuable source of competitive advantage and enhances market share (Navarro et al., 2012). Hence, based on above views this study hypothesize the following:

H1: Product development is significantly related to the firm performance.

\subsubsection{Competitive Strategy}

Competitive strategy refers to firm's ingridient of competition in an industry (Beard \& Dess 1981), competitive strategy emphasis is on how a firm competes with its' products or market segment in an industry. The strategy enable firm to create unique product and services in the process to sustainin competitive advantage (Slater \& Olson, 2001). Therefore, competitive strategy can enhance firm's competitiveness and performance (NBS \& SMEDAN, 2012). The logic is to integrate, reconfigure and build SME competency, in order to enhance their product market competitive advantage and enhance performance. previous studies have examined the mediating role of competitive strategy (see. Gmelin \& Seuring, 2014; Hernández-Perlineset al., 2016; Lechner \& Gudmundsson, 2014), these studies were conducted in the European countries. In a competitive environment like Nigeria, a competitive strategy would support SMEs to improves in research and development (R\&D), innovation, technological development, and marketing, which in turn will increase competitive advantage and sustain performance. Therefore, based on above views the study hypotheses the following:

H3: Differentiation mediates the relationship between market development and firm performance.

H4: Differentiation mediates the relationship between product development and firm performance.

\subsection{Research Framework}

Below framework illustrates the mediating effect of differentiation on the relationship between market development, product development, and firm performance.

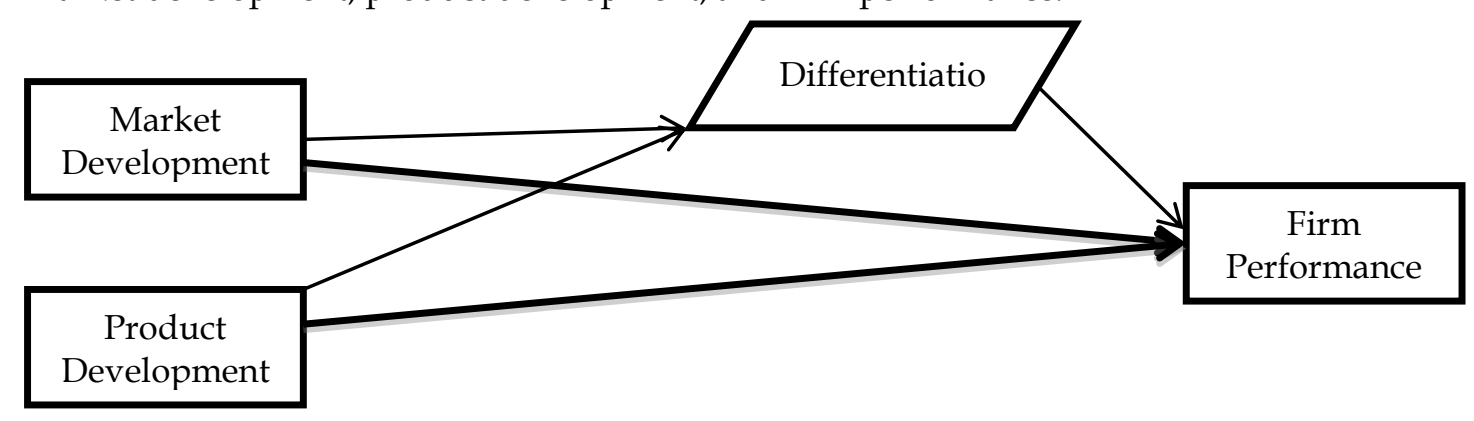

Figure 1.1-Research framework 


\subsection{Methodology}

\subsection{Sample and data collection}

The study investigates the registered manufacturing based SMEs in Nigeria (NBS \& SMEDAN, 2012) that comprise the population of 1,814 in the Northwest. About 1,420 SMEs equivalent to $78 \%$ are located in three states. The study is in line with the previous studies of (Gado \& Nmadu, 2012; Sokoto \& Abdullahi, 2013). This study has a sample of 302 SMEs (Sekaran \& Bougie, 2013). The sample was increased to 453 (Bartlett et al., 2001), to avoid nonresponse and sample size error. 453 questionnaires were proportionately distributed to SMEs located at; Kaduna 87, Kano 312 and Sokoto 54. The study received $329(73 \%)$ out of 453 questionnaires, 26 questionnaires were rejected, left with 303 (67\%). SPPSS V23 was employed for the data screening, for further SEM analysis. 10 items were replaced for missing data, and 26 cases having +/-3.29 was deleted for the univariate outliers. The study was left with 277 (61\%) cases, which were used for further analyses.

\subsection{Data Analysis}

\subsection{Demography of Respondents}

The profile of respondents, descriptive result revealed that $35 \%$ of the respondents are managers, while $27 \%$ and $21 \%$ are owners and CEO respectively. About $70 \%$ are male, while only $30 \%$ are female. The educations of the respondents $35 \%$ with first degree, while $30 \%$ have ND or NCE, while $20 \%$ have SSCE, only $15 \%$ have a master degree and only $0.7 \%$ has Ph.D. The results show $25 \%$ are sole proprietorship; $26 \%$ are limited liability firms, and $41 \%$ are in partnerships, while $9 \%$ are joint ventures. The analysis indicated that the majority of SMEs are medium with an average of $57.8 \%$, whereas $42.2 \%$ are small firms. As for the location of the business, Kano with about $67.5 \% ; 19.9 \%$ located at Kaduna and Sokoto have only $13 \%$. In response to the years of operation, the result shows $39 \%$ are between 1 to 5 years, while $21 \%$ are between 6 to 10 years. Only $18 \%$ operates between 11 to 15 years.

\subsection{Measurement Model Analyses}

To determine the individual constructs measures validity and reliability, the two-step modelling approach was used as recommended by Henseler, Ringle and Sinkovics (2009). First started with measuring the convergent validity and reliability, followed by discriminant validity. Below Table1 indicates the internal consistency and reliability. As suggested the rule of thumb, construct validity is to determine if the loadings each item are greater than 0.7; composite reliability also is greater than 0.7; average variance extracted should be greater than 0.5 (Henseler, Ringle, \& Sarstedt, 2014).

\begin{tabular}{lllll}
\hline Constructs & Items & Loadings & CR & AVE \\
\hline \multirow{4}{*}{ Market Development } & MD_1 & 0.800 & & \\
& MD_2 & 0.720 & 0.820 & 0.530 \\
& MD_3 & 0.600 & & \\
Product Development & MD_4 & 0.760 & \multirow{2}{*}{0.510} \\
& PD_1 & 0.720 & 0.760 & \\
Differentiation & PD_2 & 0.730 & & \\
& PD_4 & 0.690 & & \\
& DF_2 & 0.720 & 0.830 \\
Firm Performance & DF_4 & 0.700 & & \\
& DF_5 & 0.750 & & \\
& DF_7 & 0.750 & \multirow{2}{*}{0.830} \\
\hline
\end{tabular}


Table 1. Result of Measurement Model Reliability and Validity $(n=277)$

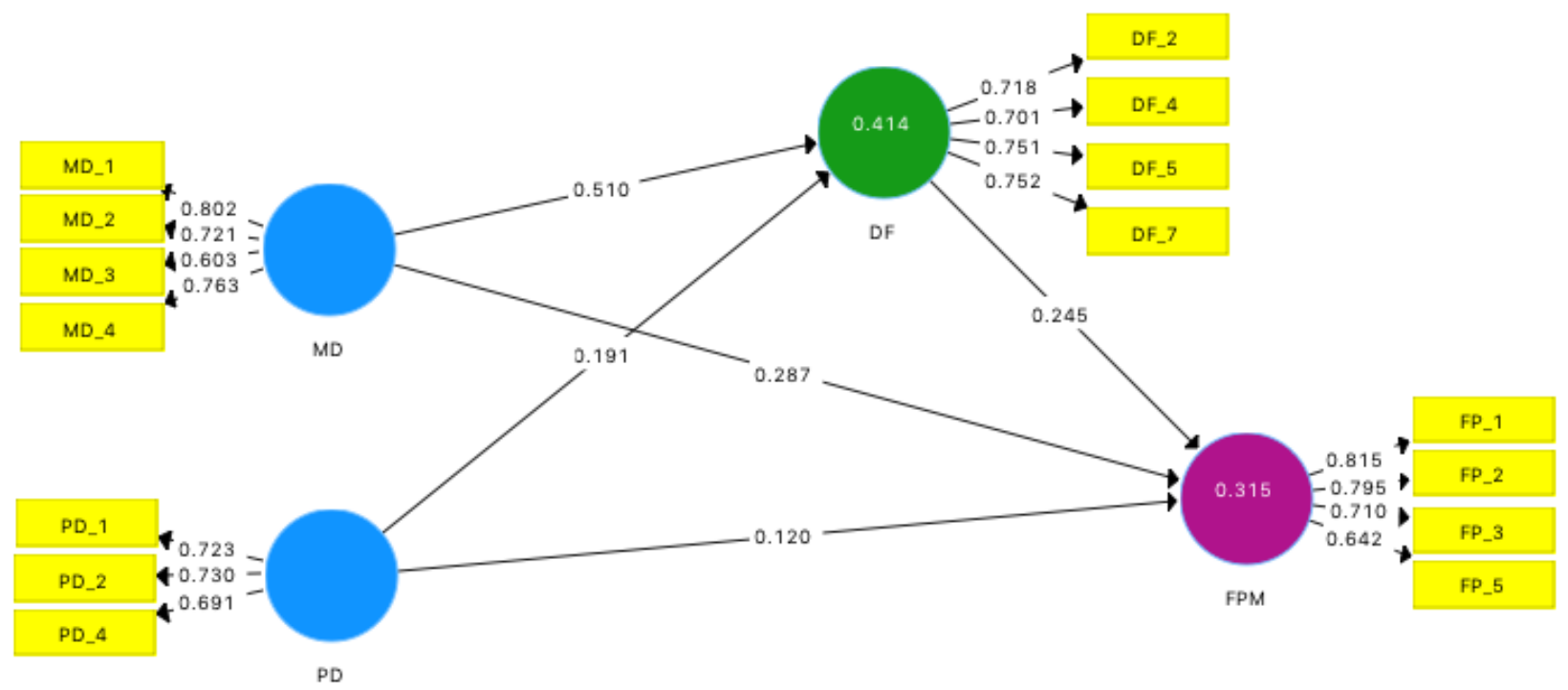

Figure 1 SmartPLS Algorithsm (Measurement Model)

In order to meet the threshold of CR 0.70 and above, and AVE 0.50 and above, the following items were deleted MD 2 items, PD 3 items, DF 4 items, FP 6 items, as recommended by (Hair, Hult, Ringle, \& Sarstedt, 2014). In this study CR value for all the constructs were above the threshold value, the CR range from 0.760 to 0.830 , this indicates the reliability of the measurement model. The convergence validity of the constructs, where the constructs explain half of the variance of their indicators, the result indicates the AVE values ranging from 0.510 to 0.550 ; this concludes that the convergent validity is established.

\begin{tabular}{lllll}
\hline Constructs & $\mathbf{1}$ & $\mathbf{2}$ & $\mathbf{3}$ & $\mathbf{4}$ \\
\hline Market Development & 0.730 & & & \\
Product Development & 0.600 & 0.720 & & \\
Differentiation & 0.620 & 0.500 & 0.730 & 0.740 \\
Firm Performance & 0.510 & 0.410 & 0.480 & \\
\hline
\end{tabular}

Table 2. Discriminant validity (Fornell-Lerckert)

\begin{tabular}{lllll}
\hline Constructs & $\mathbf{1}$ & $\mathbf{2}$ & $\mathbf{3}$ & $\mathbf{4}$ \\
\hline Market Development & & & & \\
Product Development & 0.990 & & & \\
Differentiation & 0.860 & 0.810 & 0.680 & \\
Firm Performance & 0.690 & 0.670 &
\end{tabular}

Table 3. Discriminant validity (HTMT)

Discriminant validity was measured to see the uniqueness of each construct (Hair et al. 2014). The study measured discriminant validity using Fornell-Larckert criterion (Hair et al. 2014), and Henseler's heterotriait-monotraitt ratio (HTMT) of correlation as recommended by Henseler et al., (2014). Thus, the discriminant validity was measured by comparing the square root of the AVE for each construct with the correlation presented in the matrix. Table 2 above presents the results of the Fornell-Lerckert. Also supported by HTMT result presented in Table 3, thus, discriminant validity is established with $\mathrm{HTMT}_{0.90}$. 


\subsection{Hypotheses Testing and Results}

This study tests the relationship between market development and product development on the performance of manufacturing based SMEs in Nigeria. The result of the hypotheses is summarized in Table 4 below. $\mathrm{H1}$ result indicates that market development has positive and significant influence on firm performance (Beta value at $=0.410 ; \mathrm{t}=5.640$ ). Hence, $\mathrm{H} 1$ is supported. Similarly, the hypothesis $\mathrm{H} 2$ the result shows that product development has positive and significant impact on firm performance (Beta values of $=0.170 ; \mathrm{t}=2.330$ ) and therefore, $\mathrm{H} 2$ is supported.

\begin{tabular}{llllll}
\hline Hypo. & Relationship & Beta & STD Error & T -Value & Decision \\
\hline H1 & Market Development -> Firm Performance & 0.410 & 0.070 & $5.640^{*}$ & Supported \\
H2 & Product Development -> Firm Performance & 0.170 & 0.070 & $2.330^{* *}$ & Supported \\
\hline
\end{tabular}

Table 4. Structural Model; Bootstrapping for Direct Relationship $(n=277)$

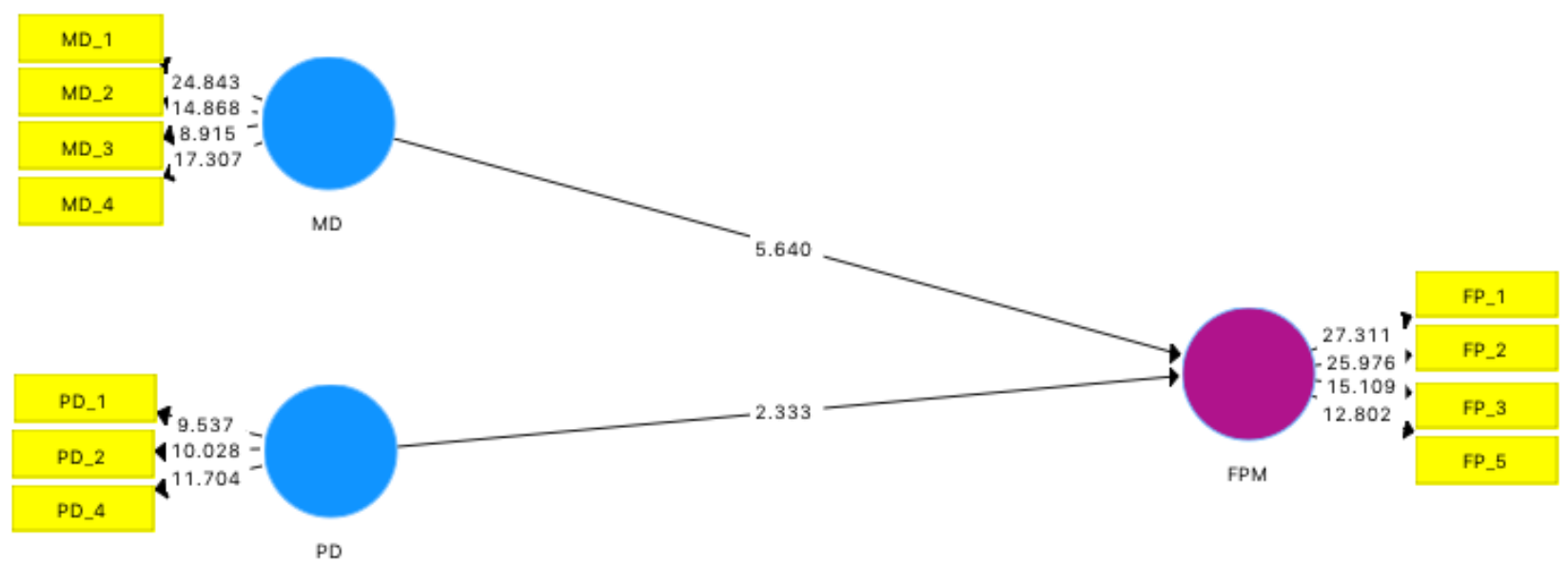

Figure 2 SmartPLS Bootstraping (Direct Relationship)

The study also measures the total effect size (f2) to see the contribution for each construct. Table 5 below demonstrates the measurement of the total effect size f2. Is consistent with the rule of thumb for f2, the effect size for the MD contributions can be considered as small the $\mathrm{f} 2$ is 0.146 ; for the PD effect size the contributions can be interpreted as small the $\mathrm{f} 2$ is 0.025 as suggested by Cohen (1988).

\begin{tabular}{lllll}
\hline Effect Size & Included & Excluded & $f^{2}$ & Effect size \\
\hline Firm Performance & 0.281 & & & \\
Market Development & 0.281 & 0.176 & 0.146 & Small \\
Product Development & 0.281 & 0.263 & 0.025 & Small \\
\hline
\end{tabular}

Table 5. Total Effect Size $\left(f^{2}\right)$

The study measured the predictive relevance, which indicates the predictive relevance of the model, shows the Q2 values achieved 0.14, using blindfolding procedure, to confirm the Q2 is greater than zero (Hair et al. 2014) see Table 6 below. The result indicates that the variables contributes only $14 \%$, this indicates there are other factors that can enhance the model.

\begin{tabular}{llll}
\hline Total & SSO & SSE & Q $^{2}$ (=1-SSE/SSO) \\
\hline Firm Performance & $1,108.00$ & 948.81 & 0.14 \\
\hline
\end{tabular}

Table 6. Predictive Relevance $\left(Q^{2}\right)$

The test of mediating effect of differentiation was determined using advanced PLS-SEM bootstrapping. Table 8 below presents the results summary. As the standard error (SE) is determined on 
the basis of bootstrapping results of the indirect effects (bootstrapping $a^{*} b$ ), whereas $t$ value was determined as a*b/SE (Hair, Hult, Ringle, \& Sarstedt, 2016). Based on the results below, differentiation strategy mediates the relationship between market development and firm performance (Beta value at $=0.125, \mathrm{t}=2.907)$. Also, differentiation mediates the relationship between product development and firm performance (Beta value at $=0.047, \mathrm{t}=2.323$ ). Hence, $\mathrm{H} 3$ and $\mathrm{H} 4$ are supported. This indicates that the twoindirect effect was empirically supported, as presented in Table 8, the confidence interval supported the results, also relies on the bootstrapping standard error (Hair et al. 2014; Hayes \& Preacher 2010).

\begin{tabular}{llllll}
\hline Hypo. & Indirect Relationship & $\begin{array}{l}\text { Beta } \\
\mathbf{a}^{*} \mathbf{b}\end{array}$ & STD Error & T Value & Decision \\
\hline $\mathrm{H} 3$ & MD ->DF*DF->FPM & 0.125 & 0.043 & $2.907^{*}$ & Supported \\
H4 & PD->DF*DF-> FPM & 0.047 & 0.020 & $2.323^{* *}$ & Supported \\
\hline
\end{tabular}

Table 7. Structural Model; Test of Significance for Mediating Relationship

\begin{tabular}{lllllll}
\hline Hypothesis & Path $\mathbf{a}$ & Path $\mathbf{b}$ & Beta $\left(\mathbf{a}^{*} \mathbf{b}\right)$ & LL2.5\% & UL97.5\% & Decision \\
\hline H3 & 0.51 & 0.245 & 0.125 & 0.040 & 0.245 & Supported \\
H4 & 0.191 & 0.245 & 0.047 & 0.008 & 0.126 & Supported \\
\hline
\end{tabular}

Table 8. Structural Model: Confidence Interval for mediating Relationships

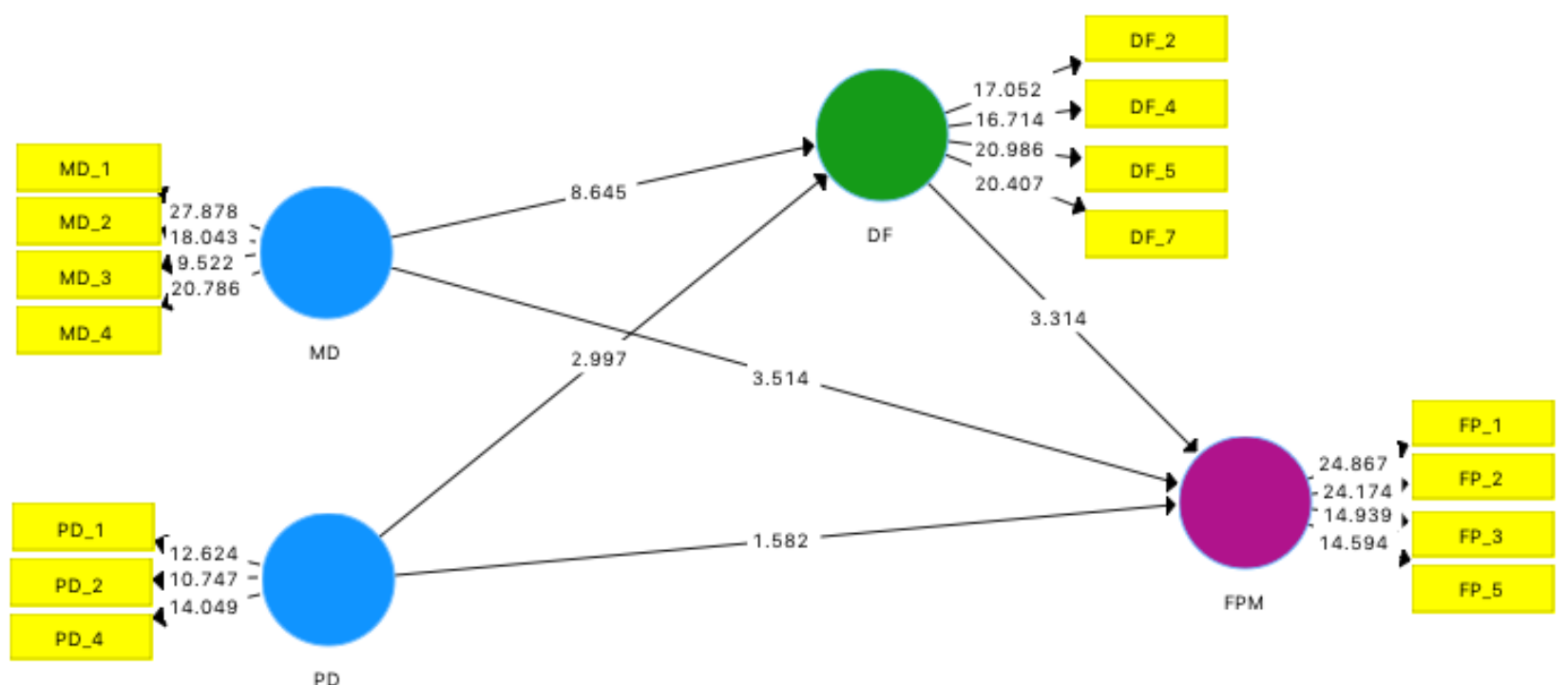

Figure 3 SmartPLS Bootstraping Structural Mode (mediating Effect)

Table 9 presents the full model predictive relevance using blindfolding result of the cross-validated redundancy $\left(Q^{2}\right)$ of the predictive endogenous latent constructs of this model indicates the $Q^{2}$ values is greater than zero for each predictive endogenous latent construct. The indicates $16 \%$ predictive relavance of the model, as such there are other factors that influnce the model.

\begin{tabular}{llll}
\hline Total & SSO & SSE & $Q^{2}$ (=1-SSE/SSO) \\
\hline Differentiation & $1,108.00$ & 878.542 & 0.207 \\
Firm Performance & $1,108.00$ & 929.961 & 0.161 \\
\hline
\end{tabular}

Table 9. Predictive Relevance $\left(Q^{2}\right)$ for mediating Relationships

\subsection{Conclusion}

The main objective of this study is to investigate the mediating effect of competitive strategy on the relationship between growth strategies and firm performance of manufacturing based SMEs in 
Nigeria. The hypotheses were tested, and the results revealed all the hypotheses (H1, H2, H3 and H4) were supported. The result of $\mathrm{H} 1$ indicates that MD significanly influence performance, the result is similar to the findings of Hussain et al. (2013) and Leitner (2014). This indicates that market development has positive impact on SME performance. Similarly, $\mathrm{H} 2$ result shows that PD has a significant influence on the performance of munufacturing based SME in Nigeria. The result support the findings of Hussain et al. (2013) and Leitner (2014), the finding of this study is also supporte by resource based view as a theory.

The study examined the mediating effect of competitive strategy (indirect relationship) hypotheses, $\mathrm{H} 3$ and H4. The PLS-SEM path results revealed that $\mathrm{H} 3$ differentiation mediates the relationship between MD and firm performance. The findings supported the study of Hernández-Perlines, et al., (2016). H4 the result indicates that differentiation explained the relationship between PD and firm performance. This result also supports the previous study of Lechner and Gudmundsson, (2014). Previous studies have shown that MD and PD can sustain firm performance through mediating effect of other factors (Hussain et al., 2013; Leitner, 2014). Products innovation and marketing capabilities on product-market development can improve competitive advantage and sustain performance (Lechner \& Gudmundsson 2014), also confirmed that competitive strategy matters for SMEs, as differentiation strategy appears to require little investment with less risk to position firm's competitiveness in the industry, and improve product quality and innovation. Therefore, the results of this study support (Lechner \& Gudmundsson 2014), proving the mediating effect of competitive strategy on the relationship between growth strategies and SME performance.

\subsection{Contributions}

The results of this study show that all the sample study engage in growth strategies and competitive strategy to enhance performance. the study supports assumption that competitive strategy matters for SMEs. Also supports the claims that growth strategies can be enhance performance through mediating variable. Therefore, all SMEs are struggling to competive, especially in developing countries like Nigeria. These firms operate in a highly competitive environment where virtually the products being produced in the country are imported. Research in strategic alignment suggests that superior performance is function of integreting appropriate firm's internal and external resources. However, strategic fit on the impact of competitive strategy on growth strategies and performance is yet to be known for SMEs. Therefore, it important for SMEs to align growth strategies with competitive strategy to create competency and enhance competitive advantage. By pursuing market development, product development and differentiation strategy to create entry barriers to their limitations.

The current study makes an empirical contribution by matching firm's strategies between growth strategies and competitive strategy to enable manufacturing based SMEs sustain performance. The finding of this study contributes to literature of growth strategies, competitive strategy and performance of manufacturing based SMEs. In addition, the findings would support management of manufacturing based SMEs toward making strategic decision, particularly, in matching a specific growth strategy with competitive strategy to remain comeptitive and enhance competitive advantage and sustain performance. Hence, this indicates that owners and managers of manufacturing based SMEs in Nigeria have shown the importance of strategic match between firm's specific growth strategy and competitive strategy toward creating competitiveness and sustain competitive advantage for superior performance.

\subsection{Limitations and Direction for Future Studies}

This finding of this study has some limitations. First the study was limited to two growth strategies of Ansoff, and only one Porter's generic typologies, hence, an extension of this work would be interesting to examine the the relationship between growth strategy, competitive stratey and performance that include sample of both small and large manufacturing based firms. That would enhance the researchers understanding and support further generalizability of the findings. Also, the measeurements of variables used in this study was limited to adapted measures from the Western countries, future studies may develop indicators that may more appropriate in this context. Secondly, the study is crosssectional in nature, and limited to manufacturing based SMEs that operates in Northwest of Nigeria. Therefore, an extension of this survey to other sectors and regions is suggested for future research. The study was conducted based on a single data source, caution must be considered when generalizing the 
findings. Finally, the survey investigates the mediating effect of differentiation strategy on the relationship between market development, product development, and firm performance of SMEs operating in the Northwest of Nigeria. An extension to other regions and comparative study would further improve our understanding on strategic match between firm's strategic orientations and competitive strategy.

\section{Reference}

Abiodun, A., 2014. SME firms performance in Nigeria: Competitive advantage and its impact. International Journal of Research Studies in Management, 3(2), pp.75-86.

Banker, R.D., Mashruwala, R. \& Tripathy, A., 2014. Does a differentiation strategy lead to more sustainable financial performance than a cost leadership strategy Management Decision, 52(5), pp.872-896.

Bartlett, J.E., Kotrlik, J.W. \& Higgins, C.C., 2001. Organizational Research: Determining Appropriate Sample Size in Survey Research. Information Technology, Learning, and Performance Journal, 19(1), pp.43-50.

Beard, D.W. \& Dess, G.G., 1981. Corporate-Level Strategy, Business-Level Strategy, and Firm Performance. Academy of Management Journal, 24(4), pp.663-688.

Beatrice, E. A., Ojera, P., Ochieng, I. \& Aila, F., 2015. Literature review on strategic fit and performance of public university in western Kenya. International Journal of Science Research and Innovation Technology, 2(6), pp.1-7.

Cohen, J., 1988. Statistical power analysis for the behavioral sciences. Lawrence Erlbaum Associates, Hillsdale, NJ, USA,

Dauda, A. \& Ismail, Y.M., 2013. Influence of technological environmental factors on the strategic choice of quoted manufacturing firms in Nigeria's food and beverage industry. International Journal of Business, Humanity, and Technology, 3(8), pp.159-169.

Dess, G. G., \& Robinson, R.B., 1984. Measuring organizational performance in the absence of objective measures: The case of the privately-held firm and conglomerate business unit. Strategic Management Journal, 5(3), pp.265-273.

Ferreira, A. \& Otley, D., 2009. The design and use of performance management systems: An extended framework for analysis. Management Accounting Research, 20(4), pp.263-282.

FME, T., 2003. Ansoff matrix strategy skills, Available at

http:/ / scholar.google.com/scholar?hl=en\&btnG=Search\&q=intitle:Ansoff+Matrix\#0.

Gado, N.D. \& Nmadu, T.M., 2012. The Performance of Textile Companies in the North West Zone of Nigeria: the Role of Infrastructure as a Resource. International Journal of Human Resource Studies, 2(1), pp.89-100.

Gmelin, H. \& Seuring, S., 2014. Achieving sustainable new product development by integrating product life-cycle management capabilities. International Journal of Production Economics, 154, pp.166-177. Available at: http://linkinghub.elsevier.com/retrieve/pii/S0925527314001406.

Hair, J.F.J., Hult, G.T.M., Ringle, C.M., \& Sarstedt, M., 2014. A Primer on Partial Least Squares Structural Equation Modeling (PLS-SEM), Available at: http://linkinghub.elsevier.com/retrieve/pii/S0024630113000034.

Hair, J.F.J., Hult, G.T.M., Ringle, C.M., \& Sarstedt, M., 2016. A Primer on Partial Least Squares Structural Equation Modeling (PLS-SEM) second edition.,

Hayes, A.F. \& Preacher, K.J., 2010. Quantifying and testing indirect effects in simple mediation models when the constituent paths are nonlinear. Multivariate Behavioral Research, 45(4), pp.627-660. Available at:

http://www.tandfonline.com.ezproxy.uwindsor.ca/doi/abs/10.1080/00273171.2010.498290\#.VYR29vlVi ko.

Henrique, G.M. de S. \& Gilberto, Miller, D.G., 2013. Predicting success in product development: The application of principal component analysis to categorical data and binomial logistic regression. Journal of Technology Management E Innovation, 8(3), pp.83-98.

Henseler, J., Ringle, C.M. \& Sarstedt, M., 2014. A new criterion for assessing discriminant validity in variance-based structural equation modeling. Journal of the Academy of Marketing Science, 43(1), 
pp.115-135.

Henseler, J., Ringle, C.M. \& Sinkovics, R.R., 2009. The use of partial least squares path modeling in international marketing. Advances in International Marketing, 20, pp.277-319. Available at: http:/ / search.ebscohost.com/login.aspx?direct=true\&db=ufh\&AN=6250585\&site=ehost-live.

Hernández-Perlines, F., Moreno-García, J. \& Yañez-Araque, B., 2016. The mediating role of competitive strategy in international entrepreneurial orientation. Journal of Business Research. Available at: http://dx.doi.org/10.1016/j.jbusres.2016.04.142.

Hussain, S. Khattak, J., Rizwan, A., \& Latif, A., 2013. ANSOFF matrix, environment, and growth- An interactive triangle. Management and Administrative Sciences Review, 2(2), pp.196-206. Available at:

http://www.absronline.org/journals/index.php/masr/article/view/102.

Irura, N.S., Onyango, G.M. \& Kerre, B.W., 2011. Collective efficiency and its effects on infrastructure planning and development for small manufacturing enterprises in Kenya. International Journal of Business and Public Management, 1(1), pp.75-84. Available at: http//:www.journals.mku.ac.ke.

Kaplan, S.R. \& Norton, P.D., 1996. Using the balanced scorecard as a strategic management system. Harvard Business Review, 74, pp.75-85.

Kongolo, M., 2010. Job creation versus job shedding and the role of SMEs in economic development. Journal of Business, 4(11), pp.2288-2295. Available at:

http://www.academicjournals.org/ajbm/PDF/pdf2010/4Sept/Kongolo.pdf.

Lamore, P.R., Berkowitz, D. \& Farrington, P.A., 2013. Proactive/responsive market orientation and marketing research and development integration. Journal of Product Innovation Management, 30(4), pp.695-711. Available at: http://doi.wiley.com/10.1111/jpim.12024.

Lechner, C. \& Gudmundsson, S. V., 2014. Entrepreneurial orientation, firm strategy and small firm performance. International Small Business Journal, 32(1), pp.36-60.

Leitner, K., 2014. Strategy formation in the innovation and market domain: emergent or deliberate? Journal of Strategy and Management, 7(4), pp.354-375.

NBS \& SMEDAN, 2012. Survey report on Micro, Small and Medium Enterprises (MSMEs) in Nigeria,

Olson, E.M. \& Slater, S.F., 2002. The balanced scorecard, competitive strategy, and performance. Business Horizons, 45(3), pp.11-16.

Pehrsson, A., 2007. The "Strategic States Model": strategies for business growth. Business Strategy Series, 8(1), pp.58-63.

Porter, M.E., 1985. Competitive advantage: Creating and sustaining superior performance. The Free Press, New York.,

Prajogo, D.I. \& Sohal, A.S., 2006. The relationship between organization strategy, total quality management (TQM), and organization performance--the mediating role of TQM. European Journal of Operational Research, 168(1), pp.35-50. Available at:

http://linkinghub.elsevier.com/retrieve/pii/S0377221704003121.

Propfe, B. Kreyenberg, D., Wind. J., \& Schmid, S., 2013. Market penetration analysis of electric vehicles in the German passenger car market towards 2030. International Journal of Hydrogen Energy, 38(13), pp.5201-5208. Available at:

http://www.sciencedirect.com/science/article/pii/S0360319913004151.

Rosli, M., 2012. Competitive strategy of Malaysian small and medium enterprises: An exploratory investigation. American International Journal of Contemporary Research, 2(1), pp.93-105.

Sekaran, U. \& Bougie, R., 2013. Research methods for business: A skill building approach 6 th ed. John Wiley $\mathcal{E}$ Son,

Slater, S.F. \& Olson, E.M., 2001. Marketing's contribution to the implementation of business strategy: An empirical analysis. Strategic Management Journal, 22(11), pp.1055-1067.

SMEDAN \& NBS, 2013. Smedan and National Bureau of Statistics Collaborative Survey: Selected Findings,

Sokoto, A.A. \& Abdullahi, Y.Z., 2013. Strengthening small and medium enterprises (SMEs) as a strategy for poverty reduction in Northwestern Nigeria. American Journal of Humanities and Social Sciences, 1(3), pp.189-201.

Soni, G. \& Kodali, R., 2011. The strategic fit between "competitive strategy" and "supply chain strategy" in Indian manufacturing industry: an empirical approach. Measuring Business Excellence, 15(2), 
pp.70-89. Available at: http://www.emeraldinsight.com/doi/abs/10.1108/13683041111131637.

Tanwar, R., 2013. Porter 's generic competitive strategies. Journal of Business and Management, 15(1), pp.1117.

Tavakolizadeh, S., 2014. Growth strategies in mature markets.

Teece, D. \& Pisano, G., 1994. The dynamic capabilities of firms: An introduction. Industrial and Corporate Change, 3(3), pp.537-556.

Teece, D., Pisano, G. \& Shuen, A., 1997. Dynamic capabilities and strategic management. Strategic management journal, 18(7), pp.509-533. Available at: http:/ / www.jstor.org/stable/3088148.

Teece, D.J., 2012. Dynamic capabilities: routines versus entrepreneurial action. Journal of Management Studies, 49(8), pp.1395-1401.

Teeratansirikool, L. Siengthai, S., Badir, Y., \& Charoenngam, C., 2013. Competitive strategies and firm performance: the mediating role of performance measurement. International Journal of Productivity and Performance Management, 62(2), pp.168-184.

Titman, S., Wei, K.C.J., \& Xie, F., 2013. Market development and the asset growth effect: International evidence. Journal of Financial and Quantitative Analysis, 48(5), pp.1405-1432. Available at:

http://www.journals.cambridge.org/abstract_S0022109013000495.

Uchegbulam, P., Akinyele, S. \& Ibidunni, A., 2015. Competitive strategy and performance of selected SMEs in Nigeria. In International Conference on African Development Issues: Social and Economic Models for Development Track. pp. 326-333.

UNIDO, 2016. Industrial Development Report 2016: The Role of Technology and Innovation in Inclusive and Sustainable Industrial Development,

Washington, O.O., 2014. The influence of business environmental dynamism, complexity and munificence on performance of small and medium enterprises in Kenya. International Journal of Business and Social Research, 4(8), pp.59-73.

Weber, P., Geneste, L.A. \& Connell, J., 2015. Small business growth: strategic goals and owner preparedness. Journal of Business Strategy, 36(3), pp.30-36. Available at:

http://www.emeraldinsight.com/doi/abs/10.1108/JBS-03-2014-0036.

Wilson, C., 2012. Strategic engagement and alignment of corporate talent. Development and Learning in Organizations, 26(5), pp.4-8.

$\mathrm{Wu}$, P., Gao, L. \& Gu, T., 2015. Business strategy, market competition and earnings management. Chinese Management Studies, 9(3), pp.401-424. 